\title{
CODE- SWITCHING AS AN EFL INSTRUCTIONAL STRATEGY: AN INSIGHT TO INDONESIAN LECTURERS' PRACTICES
}

\author{
Rahmah Fithriani \\ Universitas Islam Negeri Sumatera Utara (UIN SU) \\ Medan, Indonesia \\ E-mail: rahmahfithriani@uinsu.ac.id
}

Received: 2021-03-09

Accepted: 2021-04-26

\begin{abstract}
Studies on code-switching (CS), particularly in Indonesian EFL context have a proclivity for the occurrences i.e., its types and forms being produced by the speakers, few on their motives of practising it. This study aims to fill the void by examining Indonesian EFL lecturers' practices of CS in General English classes for first-year university students from typological and functional points of view. Involving participant observation and interview as the instruments for data collection, the results reveal that the two lecturers participated in this study employed three types of CS, namely inter-sentential switching, intra-sentential switching, and tag-switching (ordered accordingly from the mostly to the least used type). Furthermore, it is also found that the lecturers' practises of CS served three pedagogical functions: 1) to enhance students' comprehension; 2) to scaffold students' learning; and 3) to encourage students' participation. Findings suggest that strategic use of CS in instructional practices may enhance EFL teaching as well as maximize learning efficacy.
\end{abstract}

Keywords: Bilingual, Code-switching, Instructional strategy, Thematic content analysis

\section{Introduction}

In this globalized community, language contact becomes inevitable, which in turn contributes to the spread and attributed value of bilingualism. The prevalence of bilingualism, referring to the practice of alternatively using two languages (Weinreich, 1974) leads to the emergence of some linguistic phenomena. These phenomena are often characterized with the intertwinement of the elements of one language with those of other language (e.g., lexical borrowing, transferring, interference, code-switching, code-mixing, etc.) during interactions among bilingual people. One linguistic phenomenon predominantly found in bilingual speakers' interactions is code-switching, (Redouane, 2005), hereinafter referred to as CS.

CS is generally defined as the practice of switching from one language to another within either a single utterance or a same discourse (Meng \& Miyamoto, 2012). It was axiomatic that code-switching held negative connotations, commonly associated with lack of linguistic competency or even lack of intelligence (Dewaele \& Wei, 2014). Early researchers encouraged the avoidance of CS in interaction as it was a manifestation of a sloppy use of language (Kaschula \& Anthonissen, 1995) and might cause confusion and language interference (Polio \& Duff, 1994). However, over the years, CS has gradually viewed with 
favour due to abundant evidence denoting its frequent occurrences among fairly competent speakers in bilingual communities. It implies that code-switching is not a sign of language deficiency but rather an advanced control of language choice to be used in specific communicative situations (Dewaele \& Wei, 2014). This language choice is influenced by some factors such as language proficiency, topic of discussion, setting, relationships between participants, attitudes, and emotions towards a particular language (Auer, 1998; Kim, 2006).

With the positive points of view about CS, research focusing on CS in diverse fields and environments has proliferated in the past decades. One which attracts burgeoning of interest is the field of language education. The use of CS for educational purposes has been studied meticulously in diverse settings and contexts. A plethora of studies has reported various pedagogical benefits of practicing code-switching in classroom interactions, which include improvement of learning outcomes (Ahmad \& Jusoff, 2009; and Turnbull, 2001), improvement of communicative competence (Schwarzer, 2004), and enhancement of students' participation and interaction (Creese \& Blackledge, 2010; Mati, 2010).

In Indonesian EFL context, CS in educational setting has also intrigued significant interest among many researchers in the past decade. However, these studies have mostly focused on the linguistic features of the occurrences (Barus, Pujiono, \& Fibriasari, 2019; Novitasari \& Mardiana, 2020; Rahmat, 2020; Siddiq, Kustati, \& Yustina, 2020). Relatively little empirical evidence reveals why the speakers switch languages as a communicative strategy in classroom interactions. Since CS is a complex process, which involves various factors motivating the speakers to practice it, it is deemed essential to examine specific reasons behind its utilisation. Driven by the empirical gap, the present study aims to investigate Indonesian EFL lecturers' practices of CS as their instructional strategy and explore the pedagogical functions of such practices.

\section{Literature Review}

\subsection{Code Switching as an Instructional Strategy}

As previously explained, CS is prevalent in interactions among bilinguals either in formal and informal settings. Since norms of verbal interactions are both culture-specific and largely unconscious (Consolo, 2006), bilingual people tend to switch from one language to the other unconsciously. This distinct linguistic behaviour is also frequently found in interactions among foreign language learners (Almelhi, 2020). However, in certain contexts this norm of unconsciousness is not applicable. In classroom interaction for instance, since teachers play a vital role in helping students overcome linguistic barriers hindering the transmission of knowledge, they perform this practice of language alternation with being in the most aware of it. This intentional code-switching requires the speaker's sufficient knowledge of the two languages' grammatical systems to allow them to employ what rules of each system can work when being combined together. This practice is commonly known as code-switching as an instructional strategy.

In language education generally, the choice of language serves beyond its role as a medium of instruction. The language used by the teachers becomes an underpinning factor succeeding knowledge transmission from the teacher to the students. Thus, if learners do not understand the language used, they will have problems to develop educationally (BrockUtne \& Alidou, 2011). In EFL education particularly, English serves twofold; as the target 
language for students and a medium of instructions for teachers-, (Fitriyah, Dewi, Putra, \& Sulistyawati, 2020). To this end, teachers' choice of language in classroom interactions should be included as their instructional strategies

Putting its importance as an instructional strategy, CS becomes a common practice in EFL instruction.- Empirical evidence has also reported the benefits of teachers' CS for language learners in many different aspects, especially in the teaching of beginner students (Sert, 2005). For example, English classes in Indonesian EFL context are commonly instructed in the alternation of L2 (in this case is English) and L1 (Indonesian), with the use of the latter surpassing the former. The teachers consciously switch from one language to the other and vice versa for classroom communication, either in teacher-led presentation or teacherstudent interaction. This typical practice of CS takes the teachers' equal competency in both languages and serves particular pedagogical functions, which vary from one teacher to the other. Thus, related to the purpose of this study, it is always interesting to investigate specific reasons and motivations driving EFL teachers' use of CS in their instructional practice.

\subsection{Previous Studies on Code Switching in Language Education}

A myriad of studies has been conducted to investigate diverse aspects of CS practices in language education, with the preponderance denotes the advantages of using L1 in ESL/EFL contexts. These empirical evidences showing the merit of CS could later be categorised into two, namely: instructional functions and pedagogical benefits. To begin with, Azlan and Narasumand (2013) delved into how Malaysian pre-service ESL teachers used CS as a communicative tool in class interactions. Employing surveys, observations, and interviews as instruments for data collection, they found out that tag switching was mostly used when the students communicated with their peers and with the course instructor. The study also reported that the participants used CS to convey ideas in specific situations and to enhance solidarity in the first language, in this case Malay language.

In a more recent year, Adjei and Ewusi-Mensah (2019) investigated how male and female lecturers used CS in lecturer-student formal interactions in campus setting. With a sample of nine lecturers and 120 undergraduate students from a Ghana university, the study examined the types of CS in Akan-English context. The findings showed that there were three types of CS occurred in the interactions, namely: intra-sentential, inter-sentential, and CS at word, phrase and clause levels, with intra-sentential CS as the most dominant at lectures. This study also revealed the tendency of the lecturers who spoke Akan as their L1 to use CS more frequently than the non-Akan speaking ones.

In terms of pedagogical benefits, Polio and Duff (1994) undertook a qualitative study to investigate when and why university teachers shifted from the target language to their students' L1 (English) in their foreign language classes. Involving six teachers, four were the native speakers of the target language and the other two were graduate student teaching assistants, as their participants, they found that there were eight functions of CS used by the teachers, which could be categorized into three main categories, namely 1) Function of item/utterance(s) produced; 2) Difficulty of the language being used; and 3) Interactive effect involving students' use of English.

Creese and Blackledge (2010) used the translanguaging approach in their study investigating the use of two or more languages by teachers and students in Chinese- and 
Gujarati-heritage schools in the United Kingdom. Their results showed that integrating L1 and L2 improved both teachers' and students' reading comprehension, encouraged students' participation, and helped the students build identities in a multilingual and multicultural social context. Similar findings were also reported by Mati (2010) who conducted a research in a multilingual elementary class in South Africa. The teachers' use of CS in this study seemed potent on improving students' comprehension and engagement. The findings also revealed that the students found the teachers' use of CS motivating for their language learning.

Situated in ESL context, Jiang, García and Willis (2014) conducted an ethnographic inquiry to the use of L2 (English) in an L1 (Chinese) class in a U.S. bilingual program. Within a period of seven months, they observed how their primary participant, a senior Chinese teacher interacted with his five Mandarin-speaking students aged 10 and 11 in his Chinese Language Arts. The findings revealed that the teacher's strategic use of CS helped enhance students' bilingual development and maximize their learning efficacy. Specifically, the teachers used CS for five purposes, which include 1) Increasing students' bilingualism and bilingual learning; 2) Reviewing and consolidating ESL and English-language material; 3) Helping make cross-linguistic transition easier for students; 4) Improving students' awareness of home and U.S. culture; and 5) encouraging an understanding of cross-cultural differences.

Finally, Adriosh and Razi (2019) uncovered the status quo of classroom CS in EFL classrooms in Libyan universities by investigating how EFL teachers code-switched from English to Arabic to facilitate teaching/learning process. With six EFL instructors and their students from three universities as the participants in this study, they revealed that Arabic, as the participants' L1 was occasionally used for different pedagogical and social functions, which include clarification, repetition, recapitulation, and socialization. Furthermore, they also found that both teachers and students hold positive attitudes toward the use of the teacher's CS and found it necessary to facilitate learning process.

\section{Research Method}

This study was designed using an ethnographic approach. Since Ethnography relies on diverse types of data which include observations, interviews and documentation, thus provides the potential to yield detailed and comprehensive accounts of different social phenomenon (Reeves, et al., 2013), this particular research approach was chosen for this study as it allows the researcher to immerse herself in the social setting, in this case the English classroom interaction. In line with what Fraenkel, Wallen, and Hyun (1993) contended "Ethnography can reveal nuances and subtleties that other methodologies miss" (p. 508). Specifically, this study employed the exploratory ethnographic approach to explore how Indonesian EFL lecturers utilize their available language repertoires to code-switch during classroom interactions for diverse pedagogical functions.

\subsection{The Context of Study and Participants}

The study was conducted at a private university in Medan, Indonesia. Two English lecturers teaching General English classes for the first-year students were recruited to be the participants of this study. They were purposively selected because they have been using mixed languages (Indonesian and English) as their teaching practices. Table 1 provides 
Language Literacy: Journal of Linguistics, Literature and Language Teaching

Volume 5, Number 1, pp: 23-35, June 2021

e-ISSN: 2580-9962 | p-ISSN: 2580-8672

DOI: $10.30743 / I I . v 5 i 1.3622$

demographic information of the two participants using pseudonyms as their identities in this study.

Table 1: The demographics for teacher participants

\begin{tabular}{llllll}
\hline Participant & Age & Sex & $\begin{array}{c}\text { Languages } \\
\text { Spoken }\end{array}$ & Education & $\begin{array}{c}\text { Teaching } \\
\text { Experience }\end{array}$ \\
\hline Mentari & 35 & $\mathrm{~F}$ & $\begin{array}{l}\text { Javanese, Indonesian } \\
\text { \& English }\end{array}$ & $\begin{array}{l}\text { Master in English } \\
\text { Applied Linguistics }\end{array}$ & 7 years \\
Yasmine & 42 & $\mathrm{~F}$ & Indonesian \& English & $\begin{array}{l}\text { Master in English } \\
\text { Literature }\end{array}$ & 10 years \\
\hline
\end{tabular}

\subsection{Data Collection}

The data for this study were collected from observations and interviews. Due to time restriction, each lecturer participant was observed on four occasions over a period of one month. To eliminate the 'reactivity effect' from the collected data, only data from the last two observations of each participant were used with the assumption that during those observations the participants had already seen the researcher as the class dynamics, thus practiced CS as their instructional routine. A video recorder was used during the observation to gain data on how the lecturers used CS in classroom interactions. A total of four recordings, each lasted about 70 minutes were used as the data.

A semi-structured interview was conducted with each participant after all observations were completed. Each interview took place within 60-minute timeframe to collect the data related to the lecturers' motives in utilising CS as part of their instructional strategies. The interview was scheduled at the participants' convenience in terms of time and place. The responses were audio-recorded with the participants' consent and transcribed verbatim. For some questions, the participants were showed their video recording when using CS in their teaching asked questions like "Why did you insert L1/L2 words in this sentence?" or "Could you explain why you switched language here?'

\subsection{Data Analysis}

The data from video recordings during observations were thoroughly analysed to identify lecturers' use of CS. The results were transcribed and undergone further analyses to identify the types of CS based on the categories suggested by Poplack (1980) as detailed in Table 2. The results of the second phase of analysis were recorded in an Excel file to gain the quantitative calculation of the occurrences.

Table 2: Poplack's Categorisation of CS

Type of CS

Tag-switching

Inter-sentential switching

Definition

The insertion of either a single word or a tag phrase from one language into an utterance in another language.

A language switch done at a clause or sentence boundary, either words or phrases at the
Example

- Sorry ya guys kalau aku datang telat lagi.

= Sorry guys if I come late again.'

- Kalau dia, you know lah gimana. = If it's him, you know how (he is).

- Cuma orang nekat yang mau kerja sama dia, if you know what I mean. = Only reckless people want to 


\begin{tabular}{|c|c|c|}
\hline & $\begin{array}{l}\text { beginning or end of a } \\
\text { sentence. }\end{array}$ & $\begin{array}{l}\text { work with him, if you know what I } \\
\text { mean. }\end{array}$ \\
\hline $\begin{array}{l}\text { Intra-sentential } \\
\text { switching }\end{array}$ & $\begin{array}{l}\text { The shift done by inserting } \\
\text { words or phrases from one } \\
\text { language into another } \\
\text { language, usually in the middle } \\
\text { of a sentence. The speaker is } \\
\text { usually unaware of the shift. }\end{array}$ & $\begin{array}{l}\text { - Dari awal Saya sudah menasehati } \\
\text { dia not to do stupid things before } \\
\text { thinking thoroughly tapi tak } \\
\text { pernah didengarkan. } \\
\text { = Since the very beginning I have } \\
\text { reminded him not to do stupid } \\
\text { things before thinking thoroughly } \\
\text { but he never listens. }\end{array}$ \\
\hline
\end{tabular}

For the data analytical tool, Inductive Content Analysis as proposed by Terrell (2016) was employed in this study. This particular tool was used to answer the research question related to the pedagogical functions of lecturers' use of CS by identifying themes in selected data from the interview transcripts. The transcription of the interviews with the participants were contextually analysed through three coding stages; firstly, important quotations and passages were coded manually using colour pencils; secondly, the results of the initial findings from the first stage of coding were further analysed at sentence level for coding and temporary categorization; and finally, the results from this stage of coding were analysed again at the final coding stage. This process was iterative until a fair saturation of categories and subcategories could be achieved.

\section{Results and Discussion}

The analysis of the data collected through the four observations showed that L2 (English) was predominantly used as a means of instruction in EFL undergraduate classrooms in Indonesia. Similarly, the data obtained from the interviews revealed the lecturers' inclination to use English as the language of instruction in their classes. The findings discussed in correlation with the purpose of the study will be divided into three; the types of CS used by the lecturers and their aimed pedagogical functions in practicing CS.

\subsection{Types of Lecturers' CS}

The results of the first data analysis regarding the typological aspect of the lecturers' use of CS disclosed that all three types of code-switching proposed by Polack (1980) were present in the classroom interactions. In total, there were 75 instances where CS occurred (look at Table 3 for details). Out of this number, 52 examples show inter-sentential codeswitching, 17 intra-sentential switching, and only 6 instances belong to the category of tag-switching. This implies that basically CS practised by the lecturers was not done on subconscious or habitual basis but a deliberate teaching strategy.

Table 3: Occurrences of Teachers' Use of CS

\begin{tabular}{|c|c|c|}
\hline CS Used & Frequency & Percentage \\
\hline Tag-switching & 6 & $8 \%$ \\
\hline $\begin{array}{l}\text { Inter-sentential } \\
\text { switching }\end{array}$ & 52 & $69 \%$ \\
\hline $\begin{array}{l}\text { Intra-sentential } \\
\text { switching }\end{array}$ & 17 & $23 \%$ \\
\hline Total & 75 & $100 \%$ \\
\hline
\end{tabular}


Most of lecturers' use of CS occurred inter-sententially. This type of CS is seen to be occurring mostly in compound and complex sentences where one of the clauses is codeswitched entirely. Based on the data from observations, the two lecturers frequently used inter-sentential type of CS by beginning the utterance in English and ending it in Indonesian (look at examples 1 and 2 in Table 4). For the tag-switching, the lecturers usually inserted the tag phrase either in the beginning (example 7 in Table 4) or at the end (example 8 in Table 4) of the sentences. Interestingly, the lecturers used the intra-sentential CS only when using Indonesian as the language of interactions by inserting English phrases or clauses in medial position of an utterance as seen in examples 4 and 5 in Table 4 . This particular insertion of L2 into L1 in intra-sentential switching might be attributed to the practice of CS due to habitual reasons which happened because of "an affective reason related to the qualification and experience of the teachers than students' needs" (Adriosh \& Razi, 2019, p. 8).

Table 4: Examples of lecturers' CS identified in the data

\begin{tabular}{|c|c|c|}
\hline Type & Examples Found in Data & $\begin{array}{c}\text { Code in Data } \\
\text { Analysis }\end{array}$ \\
\hline \multirow[t]{3}{*}{$\begin{array}{l}\text { Inter- } \\
\text { sentential } \\
\text { switching }\end{array}$} & $\begin{array}{l}\text { 1. The word prevalence here means sesuatu yang lumrah } \\
\text { atau lazim terjadi } \\
\text { (= The word prevalence here means something commonly } \\
\text { happens/occurs). }\end{array}$ & CS-17 \\
\hline & $\begin{array}{l}\text { 2. For the exercise, you need to explain why you like the film } \\
\text { dan cukup ditulis satu paragraph aja ya } \\
\text { (= For the exercise, you need to explain why you like the } \\
\text { film and just write in one paragraph). }\end{array}$ & CS -34 \\
\hline & $\begin{array}{l}\text { 3. Good morning, class! How are you today?... Gimana akhir } \\
\text { pekannya? } \\
\text { (= how's your weekend?) }\end{array}$ & CS-23 \\
\hline \multirow[t]{3}{*}{$\begin{array}{l}\text { Intra- } \\
\text { sentential } \\
\text { switching }\end{array}$} & $\begin{array}{l}\text { 4. Kalau text-nya susah dipahami, catat yang menurut kalian } \\
\text { unfamiliar words and consult your dictionary untuk } \\
\text { mencari artinya } \\
\text { (= If the text is difficult to comprehend, write down the } \\
\text { unfamiliar words and consult your dictionary for the } \\
\text { meaning). }\end{array}$ & CS-19 \\
\hline & $\begin{array}{l}\text { 5. Rizky, tolong ambilkan marker from the office ya } \\
\text { (= Rizky, please take a marker from the office). }\end{array}$ & CS-42 \\
\hline & $\begin{array}{l}\text { 6. As you can see here, the two contrasting colours are } \\
\text { juxtaposed, dbandingkan dengan cara berdampingan, to } \\
\text { get its luminous effect. } \\
\text { (= compared by placing it side by side). }\end{array}$ & CS-57 \\
\hline \multirow[t]{2}{*}{$\begin{array}{l}\text { Tag- } \\
\text { switching }\end{array}$} & $\begin{array}{l}\text { 7. Yuk, open your handbook page } 26 \text { ! } \\
\text { (=Come on, open your book page } 26 \text { ) }\end{array}$ & CS-04 \\
\hline & $\begin{array}{l}\text { 8. I think I had explained it before, sudah kan? } \\
\text { (=I think I had explained it before, hadn't I?) }\end{array}$ & CS-63 \\
\hline
\end{tabular}

These findings echo those of Azlan and Narasumand's (2013) who found that the three types of CS were predominantly used in classroom interactions between the instructor and the students and between students and students with the inter-sentential switching as the 
most employed type to be used and the tags-witching as the least used one. However, this result is conflicting with what Adjei and Ewusi-Mensah (2019) reported in their study as they found that intra-sentential switching outnumbered inter-sentential one with the ratio of 102 to 12 occurrences.

\subsection{Pedagogical Functions of Lecturers' CS}

The analysis of the data collected through interviews revealed that most of the times the two lecturers deliberately practised CS, particularly when employing inter-sentential type for different pedagogical purposes. Through thematic content analysis, the data analysis yielded three main functions as elaborated in the following sub-sections.

\subsubsection{Theme 1: To enhance students' comprehension}

The first pedagogical function of lecturer's use of CS in this study is to enhance students' comprehension. The teachers admitted that they often inserted Indonesian phrases or sentences into English utterances and shifted from English to Indonesian to help the students understand the messages they were trying to convey as what stated in Excerpt 1 below.

\begin{tabular}{|c|c|}
\hline I (interviewer) & $\begin{array}{l}\text { : Why did you switch to Indonesian here? (I pointed to CS-34 } \\
\text { as seen in Table 4) }\end{array}$ \\
\hline Teacher 1 (T1) & $\begin{array}{l}\text { Many times, when I tell them (students) it's time to do the } \\
\text { exercise, there are always students (who) make mistakes } \\
\text { like not understanding what to do or not following the } \\
\text { requirements for the minimal words or the page length. So } \\
\text { now I always explain them (about the exercise) in } \\
\text { Indonesian so I don't need to waste time to ask them revise } \\
\text { it (Mentari, Interview, Excerpt } 1 \text { ) }\end{array}$ \\
\hline
\end{tabular}

Mentari explained that to help her students understand her instruction well and to avoid unnecessary mistakes due to misunderstanding the instruction, she deliberately switched the language of instruction.

This finding conforms Jiang, García, and Willis' (2014) claim about the role of CS through "the insertion of L2 key words/phrases within the L1 syntax ... may enhance the comprehensibility of input (and) promote comprehension (p. 323). The use of CS from L2 to L1 to help students comprehend the messages communicated was also reported in the study of Polio and Duff (1994) who found that the teachers switched to English (L1) from the target language (Korean) when receiving no response from the students. However, they also argued that the comprehension failure was not only from the students' side but also from the teachers due to "the lack of necessary experience or strategies to rephrase and otherwise modify their speech" (p. 323). Similar to this purpose, the teachers in Siddiq, Kustati, and Yustina's (2020) study also frequently used CS by shifting to L1 and even to the students' mother tongue "to help the students to comprehend the materials" (p. 88).

\subsubsection{Theme 2: To facilitate students' learning}

The next function of the lecturers' practices of CS during their teachings was to facilitate students' learning. The teachers were observed in several occasions employed CS by inserting Indonesian words or phrases into English sentences. This strategy was advertently 
done to illuminate new concepts, which many of the students were unfamiliar prior to the CS practice with the hope that they could bridge the meaning from L2 to L1. This particular function of CS was evident in classroom interactions as seen in the examples of CS-17 and CS-57 in Table 4.

The teachers' interview data also showed that L1 was often used to scaffold students' learning when the lecturers needed to introduce and/or to discuss academic vocabularies used in the course materials as observed in Excerpt 2 below:

T2 : Sometimes I encountered big words in the handouts which I know most of my students perceived them difficult to understand the meaning. So I just added the translation (of the words) in Indonesian directly after I mentioned the words.

Why did you switch to Indonesian here? (I pointed to CS-34 as seen in Table 4)

I : Do you think this strategy works well?

T2 : Of course, cause I often see them use the words in their sentences correctly (Yasmine, Interview, Excerpt 2)

In the above extract, the lecturer indicated the facilitating function of CS for students' learning. She mentioned that it is not uncommon that the learning materials employ some sophisticated terminologies that are not familiar to the students. Thus, the students' L1 was used to overcome this issue.

The use of CS to help bridge students' background knowledge to new one is also suggested by Cole (1998) who postulated that students' previous experience in learning L1 can be used to increase their understanding of $L 2$ through the use of CS as instructional strategy. Similar to this, Jiang, García, and Willis' (2014) ratified through some examples in their study that CS could function as "a medium through which bilingual children bridge the concepts and linguistic forms embedded in two languages ... thus, CS) not only enhances the acquisition of linguistic forms, such as vocabulary, but also strengthens conceptual construction (p. 323).

The function of CS use to facilitate student learning was also reported in other studies (Jiang, García, \& Willis, 2014; Sert, 2005). Jiang, García, and Willis (2014) found that the students in their study could use equivalent terms in L2 (English) in a new context after the teacher introduced them through the use of L1. They further argued that this comprehension is an "evidence of cross-linguistic transfer" (p. 320). Meanwhile, Sert (2005) found that the teacher in his study shifted from L2 to L1 in dealing with particular grammar points. He furthermore posited that when practising this function of CS "the students' attention is directed to the new knowledge by making use of code switching and accordingly making use of native tongue" (The Functions of Teachers' Code-Switching section, para. 2),

\subsubsection{Theme 3: To encourage students' participation}

The last function of lecturers' CS practise generated from the analysis is to encourage students to participate in the on-going classroom interactions. For this purpose, the two lecturers tended to switch to Indonesian at the end of sequential sentences about one related topic as can be seen in the exchange from observation below. 
continued talking]

If you have any questions, just raise your hand. You can use either English or Indonesian. Jadi semua sudah jelas ya? (= so everything is already clear right?)

[three students raised their hands signalling they had questions about the lecturer's explanation

T2 : Yes, [mentioned the student's name].

Student 1 : I have a question mam. [ then continued speaking in Indonesian]. (Yasmine's class interaction, Observation four, Excerpt 3)

In Excerpt 3 above, the interaction between the lecturer and the students was initially initiated in English. However, since the students did not give the responses the lecturer expected due to language barrier, she switched to Indonesian which seemed successful in making them participate.

This particular function was confirmed by the lecturer during the interview. She advertently switched to Indonesian as an effort to invite her students' responses to her explanation as seen in Excerpt.

I know if I keep using English, it's less likely they (the students) will ask me although they didn't understand (the material) at all. Not because they don't understand my invitation (to ask questions), they're just afraid to use their English, afraid if the grammar is wrong or they don't say it right. That's why I switched to Indonesian so they can also ask me in Indonesian (Yasmine, Interview, Excerpt 4)

The use of L1 to encourage students' participation is also found in the study of Polio and Duff's (1994) who observed that their Korean teacher participant switched to English (L1) after getting no response from the students. Student's response after the lecturer in this study code switched to their L1 may also be seen as the function of CS to emphasize group identity. Adjei \& Ewusi-Mensah (2019) revealed in their study that the lecturers switched to the students' L1 to "close the status gap between them... Once this status gap is bridged, the lecturers identify themselves with the group and group solidarity is expressed" (p. 31).

\section{Conclusion}

This present study sought to investigate how two Indonesian EFL lecturers used CS as part of their instructional strategies in teaching General English classes for first-year university students from typological and functional points of view. On a typological point of view, the findings revealed that the predominant type of CS used by the lecturers is intersentential switching, followed by intra-sentential switching and tag-switching respectively. On a functional point of view, the lecturers, in most cases used CS deliberately for different pedagogical functions, which include to help their students better comprehend the materials and/or their explanation, to scaffold the students in learning new unfamiliar concepts, and to make the students participate in the classroom interactions.

In addition to shedding a light on how interactions occur in university EFL classrooms, the findings of this study have a number of pedagogical implications. First, studies such as 
this can suggest that instead of viewing CS as an interference in foreign language learning, it should be seen as an instructional tool that help bridge between students' L1 and the target language they are learning. These findings could also raise EFL educators' awareness of how they use their language repertoire, in this case the practise of switching from L1 to L2 and vice versa, in the classroom to make the teaching learning process more effective. Being aware of their teaching practices is essential for language teachers before they could apply knowledge or skills they have learned (Freeman, 1989).

In spite of being an exploratory endeavour, this study contains limitations in several ways. This study was conducted in limited timeframe, as a consequence the data collected for this study is on an ad hoc basis. Furthermore, this study recruited only two lecturers, both are females, as the participants. In future, more research on the use of CS in classroom interactions may use the type of data gathered from diverse sources over a long period of time, with a larger number of participants, and include both lecturers and students.

\section{References}

Adjei, A. A., \& Ewusi-Mensah, L. (2019). Code-switching and Code-Mixing among University Lecturers in Formal Interactions with Students. Journal of Language and Linguistics (JOLL), 6, 20-35. http://www.jolledu.com.ng/index.php/joll/article/view/82

Adriosh, M. \& Razi, Ö. (2019). Teacher's Code Switching in EFL Undergraduate Classrooms in Libya: Functions and Perceptions. SAGE Open, 9(2), 1-11. https://doi.org/10.1177/2158244019846214

Ahmad, B. H., \& Jusoff, K. (2009). Teachers' Code-Switching in Classroom Instructions for English proficient learners. English Language Teaching, 2(2), 49-55.

Almelhi, A. M. (2020). Understanding Code-Switching from a Sociolinguistic Perspective: A Meta-analysis. International Journal of Language and Linguistics. 8(1), 34-45. http://www.sciencepublishinggroup.com/j/ijll

Auer, J. C. P. (1998). Code-switching in Conversation: Language, Interaction and Identity. London: Routledge

Azlan, N. M. N. I., \& Narasumand, S. (2013). The Role of Code-Switching as a Communicative Tool in an ESL Teacher Education Classroom. Procedia - Social and Behavioral Sciences, 90, 458-467. https://doi.org/10.1016/j.sbspro.2013.07.115

Barus, W. S., Pujiono, M., \& Fibriasari, H. (2019). Code Mixing by Students of French Study Program State University of Medan. Language Literacy: Journal of Linguistics, Literature and Language Teaching, 3(1), 41-48. https://www.doi.org/10.30743/II.v3i1.980

Brock-Utne, B. \& Alidou, H. (2011). Active Students-Learning Through a Language They Master. In A. Ouane \& C. Glanz (Eds.). Optimising learning, education and publishing in Africa: the language factor. A review and analysis of theory and practice in mother tongue and bilingual education in sub- Saharan Africa (pp. 187- 216). Hamburg: the UNESCO Institute for Lifelong Learning (UIL).

Cole, S. (1998). The Use of L1 in Communicative English Classrooms. The Language Teacher, 22, 11-13.

Consolo, D. A. (2006). Classroom Oral Interaction in Foreign Language Lessons and Implications for Teacher Development. Linguagem \& Ensino, 9(2), 33-55.

Creese, A., \& Blackledge, A. (2010). Translanguaging in the Bilingual Classroom: A Pedagogy for Learning and Teaching? The Modern Language Journal, 94(1), 103-115. 
Dewaele, J. M. \& Wei, L. (2014). Attitudes towards Code-Switching among Adult Mono-and Multilingual Language Users. Journal of Multilingual and Multicultural Development, 35(3), 235-251.

Fitriyah, Dewi, N., Putra, O. P., \& Sulistyawati, M. E. S. (2020). Lecturers' politeness strategies and Students' Compliance in English for Foreign Language (EFL) class. Language Literacy: Journal of Linguistics, Literature and Language Teaching, 4(1), 75-91. https://www.doi.org/10.30743/II.v4i1.2463

Fraenkel, J. R., Wallen, N. E., \& Hyun, H. H. (1993). How to Design and Evaluate Research in Education (Vol. 7). New York, NY: McGraw-Hill.

Freeman, D, (1989). Teacher Training, Development, and Decision Making: A Model of Teaching and Related Strategies for language Teacher Education. TESOL Quarterly, 23, 27-46.

Redouane, R. (2005). Linguistic Constraints on Codeswitching and Codemixing of Bilingual Moroccan Arabic-French Speakers in Canada. ISB4: Proceedings of the $4^{\text {th }}$ International Symposium on Bilingualism (pp. 1921-1933).

Jiang, Y. B., García, G. E., \& Willis, A. I. (2014). Code-mixing as a Bilingual Instructional Strategy. Bilingual Research Journal, 37(3), 311-326. https://doi.org/10.1080/15235882.2014.963738

Kaschula, R. \& Anthonissen, C. (1995) Communicating across Cultures in South Africa. Johannesburg: Witwatersrand University Press.

Kim, E. (2006). Reasons and Motivations for Code-Mixing and Code-Switching. Issues in EFL, 4(1), 43-61.

Liu, D., Ahn, G., Baek, K., \& Han, N. (2004). South Korean High School English Teachers' Code Switching: Questions and Challenges in the Drive for Maximal Use of English in Teaching. TESOL Quarterly, 38(4), 605-637.

Mati, X. (2010, October). Using Code Switching as a Strategy for Bilingual Education in the classroom. Paper presented at the $28^{\text {th }}$ conference of the Association for Educational Assessment in Africa, Abuja, Nigeria.

Meng, H., \& Miyamoto, T. (2012). Input and Output in Code Switching: A Case Study of a Japanese-Chinese Bilingual Infant. International Journal of Bilingual Education and Bilingualism, 15(4), 393415.

Novitasari, E. W., \& Mardiana, W. (2020). Teacher and students Code Switching in EFL Classroom at the Second Grade of SMA PGRI I Kota Mojokerto. MAJELIS: Majapahit Journal of English Language Studies, 1(1), 26-42.

Polio, C. G., \& Duff, P. A, (1994). Teachers' Language Use in University Foreign Language Classrooms: A Qualitative Analysis of English and Target Language Alternation. The Modern Language Journal, 78(3), 313-326. http://www.jstor.org/stable/330110

Poplack, S. (1980). Sometimes I'll start a Sentence in English y termino en espanol: Toward a typology of code-switching. Linguistics, 18, 581-616.

Rahmat, A. (2020). Code Mixing in EFL Classroom: Views from English Teachers Side. AlLisan: Jurnal Bahasa, 5(2), 130-147.

Reeves, S., Peller, J., Goldman, J., \& Kitto, S. (2013). Ethnography in Qualitative Educational Research: AMEE Guide No. 80. Medical Teacher, 35(8), e1365-e1379. https://doi.org/10.3109/0142159X.2013.804977

Schwarzer, D. (2004). Student and Teacher Strategies for Communicating Through Dialogue Journals in Hebrew: A teacher research project. Foreign Language Annals, 37(1), 7784. 
Sert, O. (2005). Functions of Code Switching in ELT Classrooms. The Internet TESL Journal, 11(8). http://iteslj.org/Articles/Sert-CodeSwitching.html

Siddiq, R. A., Kustati, M., \& Yustina, L. S. (2020). Teachers' Code Mixing and Code Switching: Insights on Language Barriers in EFL Classroom. Al-Ta'lim Journal, 27(1), 80-91.

Terrel, S. R. (2016). Writing a Proposal for your Dissertation: Guidelines and examples. New York, NY: The Guilford Press.

Turnbull, M. (2001). There Is a Role for the L1 in Second and Foreign Language Teaching, but.... Canadian Modern Language Review, 57, 531-540. doi:10.3138/cmlr.57.4.531

Weinreich, U. (1974). Languages in Contact ( $9^{\text {th }}$ ed.). Berlin: Mouton de Gruyter. 